\title{
International Sentencing in the Context of Collective Violence
}

\author{
RALPH HENHAM*
}

\begin{abstract}
This article evaluates some of the theoretical and practical arguments which suggest that the potential for international trial justice to make a significant contribution towards reconciliation and peace following mass atrocity is limited. Conversely, it argues that it is possible to move beyond the current narrow conceptualisation of penality in international trials by re-thinking the ideological framework for punishment and sentencing and giving trial outcomes a greater sense of moral purpose and legitimacy in the eyes of victims and those communities seeking justice. The article argues why this is necessary and achievable through the adoption of more constructive strategies and interventions in international trial process.
\end{abstract}

\section{Introduction}

The purpose of this article is to examine the phenomenon of international sentencing $^{1}$ and to assess its significance as one of a number of possible international criminal justice (ICJ) responses for achieving the broad aims of reconciliation and peace-making in post-conflict societies. Consequently, it

\footnotetext{
* Professor of Criminal Justice, Nottingham Law School, Nottingham Trent University.

${ }^{1}$ The expression 'international sentencing' gives a misleading sense of uniformity to the penal ideology and practice of international punishment in the disparate set of institutional structures which collectively constitute the international criminal trial process. It is used here primarily with reference to sentencing in the United Nations International Criminal Tribunals for the Former Yugoslavia and Rwanda (ICTY and ICTR, respectively), with speculation as to the International Criminal Court (ICC). By contrast, internationalised sentencing generally refers to punishment in trial structures which have been specifically created to deal with the situation where the available criminal trial process in the country concerned is virtually non-existent or inadequate (for example, East Timor, Sierra Leone, Kosovo, Cambodia, Iraq). As such, sentencing within these contexts may mirror international or domestic practice, or a mixture of both, depending on how the trial structure is configured.
} 
addresses the relative role of international sentencing in peace processes and establishing order in post-conflict societies, and does so against the general context of global governance as the prevailing international relations paradigm of post modernity. Its focus is on highlighting the contribution that international sentencing currently makes to post-conflict justice and describing some of the limitations which current conceptualisations of international penality possess for achieving trial outcomes that contribute to peace and reconciliation. ${ }^{2}$

The article is divided into two distinct parts. The first considers the relevance of international sentencing as a response to the phenomenon of collective violence. The second part examines ways in which international sentencing might better reflect the diverse contexts of mass violence and the obstacles which inhibit the achievement of this objective.

\section{International Sentencing as a Response to Collective Violence}

One of the more fundamental problems which currently afflict international sentencing in all its forms concerns the justification for punishment. ${ }^{3}$ The difficulty stems from the fact that international punishment ${ }^{4}$ has found it hard to divest itself of the symbolism of so-called 'victor's justice' used to describe the proceedings in Nuremberg and Tokyo following World War II. The establishment of the ICTY and ICTR in the 1990s provided an opportunity for international sentencing to become the vehicle for achieving a different kind of 'justice' in the post-conflict states of Former Yugoslavia and Rwanda.

\footnotetext{
${ }^{2}$ It does not consider the relationship between international sentencing and other forms of justice delivery.

${ }^{3}$ This problem is well-documented; see Beresford S. 'Unshackling the Paper Tiger: The Sentencing Practices of the ad hoc International Criminal Tribunals for the Former Yugoslavia and Rwanda' (2002) 1 International Criminal Law Review 33; Dana S. 'Revisiting the Blaskic Sentence: Some Reflections on the Sentencing Jurisprudence of the ICTY' (2004) 4 International Criminal Law Review 321; Olusanya, O. Sentencing War Crimes and Crimes Against Humanity under the International Criminal Tribunal for the Former Yugoslavia (Groningen: Europa Law Publishing, 2005); Henham R Punishment and Process in International Criminal Trials (Aldershot: Ashgate, 2005); Bagaric $M$ and Morss $J$ 'International Sentencing Law: In Search of a Justification and Coherent Framework’ (2006) 6 International Criminal Law Review 191.

4 'Punishment' is used expressively to describe the intended outcome of sentencing.
} 
However, such an outcome has not easily materialised for a number of reasons. ${ }^{5}$ Most prominent among these is the continuing predominance of the retributive dynamic in international sentencing. Commentators began to realise that the rhetoric and symbolism of international sentencing discourse was often hard to justify and seemed strangely disconnected from the reality of what could (or might) be justified in the states comprising the former Federal Republic of Yugoslavia or Rwanda. Consequently, judicial assertions that particular sentences were capable of fulfilling or contributing to the achievement of various consequentialist objectives, such as deterrence, rehabilitation, reconciliation or even peace, suddenly seemed somewhat detached, autocratic and slightly vacuous.

It was not difficult to find the cause. Having been created by the United Nations primarily to preclude the possibility of impunity for those who had committed breaches of international humanitarian law in the Former Yugoslavia and Rwanda, and being established outside the locus of conflict to hear cases which usually involved only the most serious perpetrators, it was not surprising that there were difficulties in relating this internationally imposed form of justice to their local contexts. ${ }^{6}$ This failure to find a way of relating the outcomes of international sentencing to local perceptions of justice was, and continues to be, critical to the future credibility of ICJ. Without this, international penality remains at a more simplistic and reactive level; that of retributive justice. As a dynamic, retributive justice may effectively thwart or preclude the development of alternative or complementary justice mechanisms and so hinder the pathway to transitional justice in post-conflict societies. ${ }^{7}$

\footnotetext{
${ }^{5}$ Only 'reasons' which are directly relevant to international sentencing are considered here. There is no space within the remit of this chapter to examine the foreign policy and international relations context, nor the broader implications for global governance in the post Cold War era.

${ }^{6}$ See, for example, Alvarez J E 'Rush to Closure: Lessons of the Tadic Judgment' (1998) 96 Michigan Law Review 2031; Drumbl M 'Punishment, Postgenocide: From Guilt to Shame to Civis in Rwanda’ (2000) 75 New York University Law Review 1221; Drumbl $M$ 'Sclerosis: Retributive Justice and the Rwandan Genocide' (2002) 2/3 Punishment and Society 287.

${ }^{7}$ As in Cambodia; see Galabru K 'Reconciliation in International Justice: Lessons from Other Tribunals’ (2006) The Open Justice Society Justice Initiative 151. For general commentary, see; Drumbl $M$ 'Towards a Criminology of International Crime' (Washington \& Lee University Public Law and Legal Theory Research Paper Series, Working Paper No. 03-07, May 2003) 20.
} 
There is no doubt that establishing some connection between the commission of acts alleged as international crimes and the perception of what might be considered an appropriate penal response by individuals, states or the so-called international community is hugely problematic. To begin with, the fact that the meanings of deviance and law are culturally relative renders the concept of universal justice problematic. Tallgren, ${ }^{8}$ for example, raises an interesting question in her observation that the symbolism of criminal justice is an important function of risk control in both international and domestic contexts. ${ }^{9}$ Clearly, Foucault's depressing vision of diminishing individual autonomy in the wake of increasing technologies of power is consistent with the increasing gulf that has developed between the rhetoric of social control and the reality of most western states' inadequate response to crime. However, whilst this analysis appears to hold for both local and global forms of criminal justice, it is theorised at such an abstract level as to ignore the social reality of crime.

Similarly, as Tallgren suggests, ${ }^{10}$ there appears to be some validity in raising a deontological objection to ICJ in that the ends cannot be made to justify the means, because it impossible to verify empirically whether international sentences do in fact contribute to peace and reconciliation, or indeed whether any consequentialist justifications for sentencing are justified. Ultimately, this is a moral rather than a sociological question.

Consequently, however we theorise the presumed effects of international criminal law or punishment, the gulf between the social reality of what victims and victimised communities perceive as justice and what passes as ICJ remains. So although, as Drumbl correctly asserts, ${ }^{11}$ it is the 'operationalization of accountability that determines its legitimacy', we should perhaps conclude that the real disconnect between the universal and the particular, or the global and the local, is more to do with the perceived morality of punishment rather than its empirical justification. It is concerned with the moral relativity of law (local or global) as an imposed normative

\footnotetext{
${ }^{8}$ Tallgren I 'The Sensibility and Sense of International Criminal Law' (2002) 13 European Journal of International Law 561, 592.

${ }^{9}$ For the significance of the risk thesis in the context of sentencing dangerous offenders, see; Pratt $J$ 'Dangerousness, Risk and Technologies of Power' 28 Australian and New Zealand Journal of Criminology 3. More generally, Shearing C 'Punishment and the Changing Face of the Governance’' (2001) 3/2 Punishment and Society 203.

${ }^{10}$ Supra, note 8

${ }^{11}$ Supra, note 7, 22-23.
} 
system of social control and, more particularly, of indigenous or cultural rationales for dealing with the behaviours which the international community has collectively labelled as international crimes. ${ }^{12}$

The disconnect between the universal and the relative is magnified where international law and/or courts are transplanted into local contexts. ${ }^{13}$ As Nollkaemper points out, ${ }^{14}$ the most important legal and policy questions concern the political elites whose normative orders underpin the process of criminalisation manifested in the trial. This raises further questions about the context from which criminal norms issue and against which the conduct of the individuals concerned are measured. Consideration of such issues is fundamental to the rationalisation of punishment in international sentencing. ${ }^{15}$

\footnotetext{
${ }^{12}$ For a useful analysis of similar arguments in the context of justifying terrorism, see; Findlay $M$ 'Terrorism and Relative Justice’ Crime, Law and Social Change (forthcoming).

${ }^{13}$ For example, in relation to Cambodia, Pangalangan suggests that, rather than providing a model of criminal justice and procedure, the insertion of internationalised chambers into national systems could 'immunise' the rest of the judicial system against amendment in correspondence with international norms. In effect, the creation of an enclave of international standard justice might remove the pressures on the rest of the system to reform. It also threatens to erode, rather enforce, domestic stability, by creating a two-tier system; international standard justice for the leaders of atrocities, and domestic standard justice for their underlings; Pangalangan $R$ 'Cambodia' Paper presented at the conference, Internationalised Criminal Courts and Tribunals: Practice and Prospects, Universiteit van Amsterdam, The Netherlands, 25-26 January, 2002. Similarly, commenting on East Timor, Othman points to a number of normative difficulties relating to the hierarchy between crimes, and practical issues relating to the concurrent operation of two procedural systems in trials where the accused is charged with both 'international' and domestic crimes. Furthermore, the international authority of international ICC norms might be undermined because of inadequate resources being provided to the processes which were intended to give them substance; Othman $M$ 'East Timor' Paper presented at the conference, Internationalised Criminal Courts and Tribunals: Practice and Prospects, Universiteit van Amsterdam, The Netherlands, 25-26 January, 2002.

${ }^{14}$ Nollkaemper A 'Procedures for establishment' Paper presented at the conference, Internationalised Criminal Courts and Tribunals: Practice and Prospects, Universiteit van Amsterdam, The Netherlands, 25-26 January, 2002.

${ }^{15}$ In Sierra Leone, for example, does the fact that the UN dealt solely with government forces taint the perceived impartiality of the trial process, and therefore undermine the deterrent objectives of the trial as symbolic of a process of criminalisation? Does it instead suggest that trial and sentencing in internationalised tribunals is less focused on deterrence than retribution by the international community and its chosen local partners?
} 
The doctrinal question of the direct effect of international law within national legal orders also has a direct bearing on criminal trial processes, since it influences the manner in which international and domestic processes are reconciled. For example, in certain constitutional orders, international norms may have effect only to the extent that they do not derogate from fundamental principles guaranteed by the national constitution. In such cases, national procedural norms take primacy, with international norms playing only an influencing role. Under the trusteeship approach, however, international law predominates so that local norms play a minor influencing role.

These kinds of issues determine the nature and significance of the relationship between international and national structures in internationalised contexts. The most important aspect of this relationship for sentencing concerns the interaction between international and national normativity and its manifestation in hybrid trial processes. ${ }^{16}$ As Romano suggests, ${ }^{17}$ the key factor here is how individual judicial discretion modulates this effect to conduct the process of criminalisation. ${ }^{18}$ However, as I have argued elsewhere, ${ }^{19}$ the crucial issue remains one of understanding what this process of criminalisation actually signifies for victims and victim communities.

${ }^{16}$ Condorelli makes the important point that the hybridisation of criminal processes also reflects a wider trend towards the internationalisation of domestic judicial functions even in purely national contexts involving not just formal institutional processes but also the growth of comparative judicial methodology by judicial actors; Condorelli $L$ 'Is there a need for internationalised courts and tribunals?' Paper presented at the conference, Internationalised Criminal Courts and Tribunals: Practice and Prospects, Universiteit van Amsterdam, The Netherlands, 25-26 January, 2002.

${ }^{17}$ Romano C 'Procedures for establishment' Paper presented at the conference, Internationalised Criminal Courts and Tribunals: Practice and Prospects, Universiteit van Amsterdam, The Netherlands, 25-26 January, 2002.

${ }^{18}$ Romano suggests that 'local' judges will exercise a kind of 'local' discretion, embedded in local norms, and 'international' judges a generalised or abstracted 'international' discretion, freed from any particular perspective that would threaten its impartiality. Notwithstanding the fact that such an analysis appears to ignore the possibility that so-called 'international' discretion is partial rather than generalised and unfocused, the alternative scenario envisaging the fusion of two normative orders to constitute a uniform unilateral criminalisation of the conduct in question seems a remote possibility. More likely, where mixed benches are involved, is the effect that there may be multiple (rather than one) trial process occurring in each trial in these hybrid tribunals. ${ }^{19}$ Henham $R$ 'Some Issues for Sentencing in the International Criminal Court' (2003) 52 International and Comparative Law Quarterly 81; Henham $R$ 'The Philosophical Foundations of International Sentencing’ 1 Journal of International Criminal Justice 64. 
This realisation forces us to address the legitimacy of the penality which prevails in international and internationalised criminal trial processes and seek connections between the ideology of punishment and its moral authority.

Whilst the advent of the ICC might obviate the need for internationalised tribunals, the important lesson to be drawn from them relates to the need for justice to be made local. However, the nature and significance of this transformative enterprise differs as between international and internationalised punishment models, as made clear by Linton when describing the significance of the Serious Crimes Panels in East Timor. ${ }^{20}$ More particularly, it should be established whether, as Linton suggests, ${ }^{21}$ the purpose of the enterprise is for justice to be seen as an end in itself, or, whether it is part of a nation's strategy for moving forwards towards peace and reconciliation. ${ }^{22}$

An additional problem for international sentencing, especially in its internationalised form, concerns the difficulties in establishing a consistent relationship between trial process and other forms of resolution; something which may prove critical in achieving the correct balance between local demands for retributive and restorative forms of post-conflict justice. ${ }^{23}$ In the context of TRCs, for example, Wilson ${ }^{24}$ makes the important point that they have a tendency to equate human rights with reconciliation and amnesty rather than reflecting popular understandings of justice, with the danger that human rights discourse becomes 'the language of pragmatic political compromise rather than the language of principle and accountability'.

These effects will clearly vary according to local context, yet their resolution through achieving a principled compromise between the trial process and alternative mechanisms is hindered by the fact that some

${ }^{20}$ Linton $S$ 'Cambodia, East Timor and Sierra Leone: Experiments in International Criminal Justice’ (2001) 12 Criminal Law Forum 185, 217.

${ }^{21}$ Ibid, 243

${ }^{22}$ In the case of Sierra Leone she suggested the need for a clear policy of transitional justice to ensure that the existing work of the Serious Crimes Panels was not compromised in any way. Failure to do so would threaten notions of fair trial, including trial by media, prejudice to the presumption of innocence, the tainting of evidence and the risk of inconsistent testimony; ibid, 223.

${ }^{23}$ See further, Wilson $R$ A The Politics of Truth and Reconciliation in South Africa (Cambridge: Cambridge University Press, 2001)

${ }^{24}$ Ibid, 228. 
commentators have argued strongly that trial and punishment is an inappropriate paradigm for developing more restorative forms of conflict resolution. For example, at the theoretical level, Christodoulidis ${ }^{25}$ questions the capacity of legal rules to bring about reconciliatory functions such as 'mercy' through process, seeing law as overdeterministic and incapable of proceeding beyond the categorical abstractions imposed by the reductive nature of legal rules; that essentially complex reflexive ethical decisions cannot be reached solely within a legal context. Roche ${ }^{26}$ argues that sentencing hearings are more concerned with a victim's physical injuries and material loss than serious emotional or psychological loss, such as loss of dignity, happiness, confidence, security, personal power and sense of selfworth, and that even a modified form of trial more mindful of victims' needs, such as the ICC, 'remains an inherently unsuitable forum for pursuing reparation.'

Similarly, Parmentier ${ }^{27}$ is equally circumspect about the future potential of the ICC:

In sum, the strengths of the new ICC clearly lie in the establishment of factual truth and criminal responsibility in a limited number of individual cases, with the possibility of monetary compensation, restitution and rehabilitation for the victims. On the other hand, the Court will hardly be able to establish any collective truth for large numbers of perpetrators, or any other type of responsibility, and it will not be able to provide any symbolic or more structural measures to the victims.

Parmentier also suggests ${ }^{28}$ that the ICC's role as a complimentary institution is best seen in its capacity to link the primary loci for retributive justice (i.e. nation states). He further envisages retributive and restorative forms of justice as generally deliverable by separate mechanisms; as complimentary, each with their specific characteristics and contributions to situations of mass violence. ${ }^{29}$

${ }^{25}$ Christodoulidis E A 'Truth and Reconciliation as Risks' (2000) 9 Social and Legal Studies 179.

${ }^{26}$ Roche D 'Truth Commission Amnesties and the International Criminal Court' (2005) 45 British Journal of Criminology 565, 572.

${ }^{27}$ Parmentier $S$ 'Global Justice in the Aftermath of Mass Violence: The Role of the International Criminal Court in Dealing with Political Crimes’ (2003) 41 International Annals of Criminology 203, 211.

${ }^{28}$ Ibid, 213.

${ }^{29}$ Ibid, 216. 
Finally, Fletcher and Weinstein ${ }^{30}$ make the important point that there are 'no mechanisms to respond to the ways in which bystanders are implicated in the establishment and maintenance of societal structures that facilitate the onset and implementation of mass violence'. In their view, trials single out particular authors and perpetrators, omitting broader initiatives on rule of law, humanitarian assistance, democracy building and economic development. Consequently, Fletcher and Weinstein ${ }^{31}$ also advocate multiple interventions, and envisage criminal trials as continuing to perform an essentially retributive punishment role. ${ }^{32}$ By responding only to one dimension of the abuse of power criminal trials fail to address the phenomenon of collective power and its influence on individuals, so are unable to address the social and collective forces that lead to violence. ${ }^{33}$

As these comments suggest, a significant influence on international sentencing is that it operates within a largely adversarial framework which focuses on establishing individual responsibility for legal guilt rather than working towards developing understandings of the relationship between individual and collective responsibility, and what these might mean for reconciliation and peaceful co-existence. Tallgren $^{34}$ rightly regards this tendency for ICJ to produce 'unambiguous notions of guilt or innocence' as establishing patterns of causality which conveniently ignore the complexity and scale of multiple responsibilities that signify the social reality of collective violence and mass atrocity.

However, it is also important to consider the specific impact of retributive justice delivered within the adversarial paradigm of international trials on the nature and function of procedural norms. Each of these effects contributes in differing degrees to the limited capacity of current manifestations of international sentencing to engage with broader contextual factors and realise a more pivotal role for trial justice in post-conflict strategies for peace and reconciliation.

\footnotetext{
${ }^{30}$ Fletcher L E and Weinstein $H M$ 'Violence and Social Repair: Rethinking the Contribution of Justice to Reconciliation’ (2002) 24 Human Rights Quarterly 573, 578.

${ }^{31}$ Ibid, 624.

32 Ibid, 627.

${ }^{33}$ Ibid, 636. This, of course, begs the question as to the extent to which any form of resolution or intervention (including trials) is able to avoid contamination and deliver justice irrespective of power.

${ }^{34}$ Supra, note 8, 561.
} 


\section{Reflecting the Contexts of Collective Violence in International Sentencing}

This section aims to explore how international sentencing can respond to some of the challenges discussed above and, more specifically, hope to engage with both the individual and collective contexts of mass atrocity by delivering outcomes which can contribute more effectively to achieving justice in post-conflict societies.

It is necessary to begin by briefly ${ }^{35}$ sounding some cautionary theoretical notes. These relate chiefly to academic disputes about the nature of law and the relationship between law and morality, but they do have a significant bearing on the praxis of international sentencing. The first is the tendency for some commentators to view law as a closed system of rules ${ }^{36}$ which effectively denies the possibility for investing analyses of the processes of law and legal reasoning with any broader contextual dimensions. Similarly, the related dichotomy between law and morality argued for by others ${ }^{37}$ presents a significant obstacle to advancing the debate about rationalising international sentencing. Finally, Nelken's ${ }^{38}$ reproachful commentary regarding the limits of sociologically-orientated explanations of law and legal process serves to restrict the scope of the debate.

The reason why these diverse theoretical perspectives are so important to the present discussion concerns their impact on our capacity to advance the argument about rationalising the ideology and purpose of international

\footnotetext{
35 These issues are explored at length in Henham, supra, note 3.

${ }^{36} \mathrm{Raz}$ distinguishes between moral and legal reasoning on the basis that the latter is about reasoning about the law as it is, whereas the former concerns the relationship between law-making and politics as reflected, in particular, in the creation of legislation and lawmaking processes; Raz $J$ Ethics in the Public Domain: Essays in the Morality of Law and Politics (Oxford: Clarendon Press, 2001) 300

${ }^{37}$ Fuller L L The Morality of Law (New Haven, CT: Yale University Press,1969).

${ }^{38}$ Nelken $D$ 'Blinding Insights?: The Limits of a Reflexive Sociology of Law' (1998) 25 Journal of Law and Society 407. For a contrary view, see Cotterrell $R B M$ 'Why Must Legal Ideas Be Interpreted Sociologically?’ (1998) 25 Journal of Law and Society 171
} 
sentencing. The author has argued ${ }^{39}$ that analyses of the law and process of sentencing must be capable of explaining how law is transformed into normative guides to conduct, and that in order to appreciate the relationship between legal reasoning and punishment requires an acknowledgement that sociological insights are capable of deconstructing different legal discourses and normative systems. Consequently, it is argued that legal thought and decision-making must be conceptualised as a process to realise the moral power of the law.

Our ability to conceptualise the link between ideology, process and legitimacy is critical for understanding how moral values are realised through sentencing, as is our knowledge of how this process of transformative decision-making produces outcomes that are perceived as morally legitimate by 'significant others', especially victims and communities of justice. Hence, a common belief in the morality of justice should link the ideology and the praxis of sentencing, at whatever level.

The significance of law's transformative capacity does not, however, rest solely on its ability to reflect the moral worth of the ideology and principles which inform international sentencing, but also on the degree to which the capacity exists to conceptualise and promote competing moral claims for punishment. It is therefore pertinent to consider, in a Durkheimian sense, whether there is a tangible connection between individual morality and its manifestation as a kind of collective conscience represented in the form of universal justice or global penality. If collective concern for humanity does create a moral imperative, then how can this be realised through giving effect to international penal norms which purport to be grounded in principles of fairness and justice?

By linking moral and empirical questions in this way it becomes apparent that any project for transforming the presently exclusive retributive framework for international sentencing must address core questions about whether, and (if so), how individual and collectively held perceptions as to the morality of justice can be reflected in international criminal trials.

\footnotetext{
${ }^{39}$ Henham $R$ 'Theory and Contextual Analysis in Sentencing' (2001) 29 International Journal of the Sociology of Law 253.
} 
It is significant that it is largely through the normative analysis of international sentencing that commentators have posited possibly deeper and more fundamental ideological reasons for the disjuncture that exists between the professed justifications for international sentencing and the social reality of how its outcomes are perceived. A considerable number of weaknesses have been identified, including: ${ }^{40}$

\section{Lack of ordinal and cardinal proportionality}

The proportionality principle is integral to retributive rationality. However, it has always proved difficult to establish a relationship between the relative seriousness of different kinds of behaviour (cardinal proportionality) and the relative severity of the sentences which should be awarded for different offences, and more particularly, for different degrees of seriousness of a specific offence (ordinal proportionality). ${ }^{41}$ The problem has been exacerbated for international crimes because no clear hierarchy is established between the crimes themselves in terms of their relative seriousness and no clarification exists in the foundation instruments of the ICTY, ICTR or the ICC.

\section{The need for separate sentencing hearings}

Because testimony relating to trial and sentence is normally heard before the verdict the necessary omission of mitigation evidence may prove prejudicial to the defence when it comes to sentencing because it restricts the information concerning the individual's personal role in the commission of the crime and its immediate aftermath. ${ }^{42}$ This kind of structural device represents a significant procedural obstacle to achieving greater inclusivity for victims.

\footnotetext{
${ }^{40}$ For detailed evaluation; see, Henham, supra, note 3.

${ }^{41}$ For further analysis; see, Danner A $M$ 'Constructing a Hierarchy of Crimes in International Criminal Law Sentencing' (2001) 87 Virginia Law Review 415; Frulli M 'Are Crimes against Humanity More Serious than War Crimes?' (2001) 12 European Journal of International Law 329; Carcano A. 'Sentencing and the Gravity of the Offence in International Criminal Law’ (2002) 51 International and Comparative Law Quarterly 583

${ }^{42}$ Keller A $N$ 'Punishment for Violations of International Criminal Law; An Analysis of Sentencing at the ICTY and ICTR' (2001/2002) 12 Indiana International and Comparative Law Review 53, 68.
} 
The reality of victim participation

The substantive engagement of victims' concerns has not been effectively addressed wither as formal legalistic and procedural criteria, or in the social reality of international trial practice. ${ }^{43}$ Although, as Zappala suggests, ${ }^{44}$ the ICC statute represents an attempt to increase procedural rights for victims and expand them procedurally, this expansion may prove nothing more than symbolic rather than concrete, and have little impact on the fundamental structural weaknesses afflicting international sentencing.

\section{The relevance of rights}

Similarly, as the corollary to access, victims' rights in international sentencing merely serve to reflect the ideology and structures of retributive punishment which infuse the penality of international criminal trials. ${ }^{45} \mathrm{~A}$ more balanced notion of justice, which endeavours to connect with the developing place of victims within restorative justice and features conceptualisations of victim access and interests beyond those of individual harm and just deserts has yet to realised.

In addition to these normative failures, the ICTY in particular has increasingly championed the virtues of plea bargaining and sentence discounts in return for guilty pleas, whether or not contained in a formalised plea agreement. ${ }^{46}$ As in the Plavsic ${ }^{47}$ case, the assumption is often made the accused's guilty plea and acknowledgement of responsibility has a 'positive impact on the reconciliatory process' and should in consequence carry significant weight as a mitigating factor. It therefore accepted that guilty pleas and other expressions of remorse can contribute towards establishing

\footnotetext{
${ }^{43}$ Henham $R$ 'Some Reflections on the Role of Victims in the International Criminal Trial Process’ (2004) 11 International Review of Victimology 201.

${ }^{44}$ Zappala S Human Rights in International Criminal Proceedings (Oxford: Oxford University Press, 2003) 221.

${ }^{45}$ Henham $R$ 'Conceptualising Access to Justice and Victims' Rights in International Sentencing' (2004) 13 Social and Legal Studies 21.

${ }^{46}$ It is important to note that the Trial Chamber is not bound by any such agreement; Rule 62 ter (C) ICTY Rules of Procedure and Evidence. See further; Henham R and Drumbl $M$ 'Plea Bargaining at the International Criminal Tribunal for the former Yugoslavia' (2005) 16 Criminal Law Forum 49

${ }^{47}$ Prosecutor v Plavsic (Case No. IT-00-30\&40/1-S), Trial Chamber, Judgement, 27 February 2003.
} 
the 'truth' of what took place. However, this raises the important issue of whether such a procedural device operating in the context of a (predominantly) adversarial trial paradigm is best placed to determine 'truth', ${ }^{48}$ and indeed, raises questions about the context in which this particular version of 'truth' is being produced, and for whom. Not only do guilty pleas deny the possibility of testing the evidence in open court, the acceptance of a charge as reflecting the totality of the accused's criminal conduct effectively denies the court the opportunity to give full expression to the totality of that criminality through the imposition of a penal sanction which adequately reflects the seriousness of the crime(s) and the culpability of the offender. ${ }^{49}$

Although it may be argued that enhancing the speed of punishment, saving court time and expense, absolving the need for victim/witness testimony, encouraging cooperation with the authorities and the further identification of suspects are all beneficial consequences of plea bargains, none of these rationalisations supports a more inclusive ideology and purpose for international sentencing which provides the means for increasing the perceived legitimacy of trial outcomes for victims and communities in post-conflict societies.

Sentencers in international criminal trials have a great deal of freedom to individualise penalties through their consideration of the particular circumstances of a case and the form and degree of participation in the crime on the part of the accused. ${ }^{50}$ However, the unstructured use of discretion in a situation where the parameters set for determining the relative seriousness of offences is unclear inevitably produces obfuscation and inconsistency in sentencing. Although the wide discretionary powers possessed by international sentencers could be used to develop sentencing principles that promote more consequentialist objectives, the individualisation of sentences as currently practised fails to engage with such purposes, focusing instead on

\footnotetext{
${ }^{48}$ Zappala, supra, note 44, 89 makes the important point that the determination of 'truth' where a guilty plea is entered is neither judicial nor pedagogical, and, therefore, appears to contradict the mission of international criminal courts to take account of victims' interests.

49 See Dissenting Opinion of Judge Wolfgang Schomburg.in Prosecutor v Deronjic (Case No IT-02-61-S), Trial Chamber, Sentencing Judgement, 30 March 2004.

${ }^{50}$ See further; Henham, supra, note 3, ch 2.
} 
issues of individual criminal responsibility and its clarification within the existing retributive paradigm. Thus, the predominant ideological framework of retributivism and deterrence for international sentencing suggests a particularly narrow interpretation of individualisation which fails to engage constructively with the wider social context of sentencing outcomes and significantly restricts the potential for doing so.

Consequently, unfettered judicial discretionary power exercised within a restrictive retributive context is linked to the perceived problem of obfuscation and inconsistency in rationalising international sentences. Within this context, commentators have advocated various forms of sentencing guidance, again mainly drawing on the experiences of western adversarial forms of criminal justice. ${ }^{51}$ Whilst many states have 'mixed' systems, with proportionality as the primary aim, and other aims (such as prevention, incapacitation or rehabilitation) predominating where appropriate, this would not address the fundamental problem besetting international sentencing. Similarly, neither would Ashworth's otherwise cogent argument, ${ }^{52}$ that in order to combat the problem of 'subjective disparity ${ }^{53}$ it is necessary to establish the ideal sentencing pattern for a given jurisdiction; this being achieved by first deciding upon the aim of sentencing, or the order of priority among competing aims.

Regrettably, the reason why none of these otherwise excellent suggestions provides a satisfactory solution to the problem of rationalising international sentencing is that conventional forms of sentencing guidance would merely serve to perpetuate the status quo favouring retributive justice, or a slightly modified version thereof, since they are likely to be developed from within the institutional context and its current penal mandate. For judicial discretion to possess the flexibility to work towards clearer goals which can help to achieve justice in post-conflict societies would necessitate a fundamental re-evaluation of the mission and purpose of international sentencing. This would effectively re-position and channel judicial

${ }^{51}$ For example, Beresford, supra, note 3; Henham, 'Some Issues', supra, note 19.

${ }^{52}$ Ashworth A 'Techniques for reducing subjective disparity in sentencing' in Council of Europe, Disparities in Sentencing: Causes and Solutions, Collected Studies in Criminological Research, Vol. XXVI (Strasbourg: Council of Europe, 1989) 101-131

${ }^{53}$ It was acknowledged that the concept of 'subjective disparity' can have no constant point of reference, since its essence lies in deviations from the 'ideal sentencing pattern' in a given jurisdiction; ibid,101. 
discretionary power towards developing outcomes which resonate more with the legitimate demands of victims and victim communities for justice.

Merely increasing the participative rights of victims is insufficient if there is no change in the basic ideology and normative framework for delivering international trial justice because the overall context for international sentencing would otherwise remain dominated by the retributive dynamic. The implications of this are that international sentencing must somehow remain lacking in legitimacy for victims and communities in post-conflict societies.

Since this in not an acceptable option if international sentencing is to make a meaningful contribution towards reconciliation and building peace, it is necessary to explore exactly what legitimacy might mean in this context. It has been noted that whilst mass violence in post-conflict states may be characterised as criminality because it breaches international legal norms, punishment administered internationally for such crimes may not meet with the legitimate expectations for justice of indigenous communities.

Unfortunately, attempts to legitimise international penality by broadening its capacity to reflect pluralistic justice demands have met with limited success. For example, the ICCs investigation into Uganda's civil war has been roundly criticised for its counterproductive effect in exacerbating the prospects for achieving peace and reconciliation. ${ }^{54}$ Accusations of failure to consult with the traditional structures of local justice have similarly plagued the prospects for achieving post-conflict justice in the Former Yugoslavia and Rwanda. The collapse of the Yugoslav Truth and Reconciliation Commission after just three years is largely attributed to a failure of public consultation or debate, ${ }^{55}$ whilst alternative communitybased paradigms for dispute resolution, such as the Rwandan Gacaca

\footnotetext{
${ }^{54}$ See generally; Seils $P$ and Wierda $M$ 'The International Criminal Court and Conflict Mediation' (New York: International Centre for Transnational Justice, Occasional Paper Series, 2005) 10; for criticism, Volqvartz J 'ICC Under Fire Over Uganda Probe' CNN, 23 February 2005; Guardian Weekly 'Peace or Justice? at http://www.guardian.co.uk/guardianweekly/story/0,1987173,00.html .

${ }^{55}$ Galabru, supra, note 7, 156.
} 
courts, ${ }^{56}$ may be diluted or hybridised thereby jeopardising their prospects for contributing to the achievement of social harmony. ${ }^{57}$

The need for a deeper contextual understanding of the nature of collective violence as a precursor to seeking to reflect the relativity of justice in international sentencing outcomes is well-illustrated by de Londras's recent analysis of the relationship between sexual violence and genocide. ${ }^{58}$ Through deconstructing the context of genocidal sexual violence in terms of the intersections of sex, gender and cultural position, de Londras convincingly argues the need for effective remedies to appreciate and fully respond to these experiences. ${ }^{59}$

Findlay and Henham have consistently argued that developing credible strategies for achieving deeper contextual understanding is the key to engaging with the relativity of justice. ${ }^{60}$ In the language of intersectionality theory, this will allow us to appreciate how the axes themselves are formed, instead of simply concentrating on their intersection. ${ }^{61}$ However, an engagement with context which is capable of revealing the complexities and patterning of a penal culture that has developed over perhaps hundreds of years, and deeper still, the broader influences which have impacted on the development of such a culture, is fraught with difficulties, not least of which are the pragmatic constraints of time and resources. Nevertheless, however imperfect the result, or limited the methodological tools for its achievement, it is a goal which must be pursued if greater legitimacy for ICJ is to be realised.

\footnotetext{
${ }^{56}$ See, Goldstein-Bolocan $M$ 'Rwandan Gacaca: An Experiment in Transitional Justice' (2004) Journal of Dispute Resolution 355.

${ }^{57}$ Simon $J$ 'State Sponsored Mass Violence: Criminal Accountability and

"Reconciliation”' (Freiburg: Max Planck Institute for Foreign and International Criminal Law, 2002).

${ }^{58}$ de Londras $F$ 'Telling Stories and Hearing Truths: Providing an Effective Remedy to Genocidal Sexual Violence against Women' in Henham $R$ and Behrens $P$ (eds) The Criminal Law of Genocide: International, Comparative and Contextual Aspects (Aldershot: Ashgate, forthcoming

${ }^{59}$ Ibid.

60 This is central to the methodology of comparative contextual analysis; see further, Findlay $M$ and Henham $R$ Transforming International Criminal Justice: retributive and restorative justice in the trial process (Cullompton: Willan, 2005).

${ }^{61}$ Supra, note 58, citing Cooper D Challenging Diversity: Rethinking Equality and the Value of Difference (Cambridge: Cambridge University Press, 2004) 49.
} 
Any increase in accountability and community control over justice to ensure that it responds to local sensitivities implies some reduction in purely or predominantly retributive solutions. ${ }^{62}$ Outcomes are only likely to be deemed appropriate by victims and communities of justice if they recognise the relationship between harm and victimization and emphasise the relational context of harm and responsibility. They should also encourage contact and cooperation between conflict groups and ensure such groups have equality of representation, both of their views, and as participants in the process itself. Finally, outcomes should emphasise principles of democratic accountability, which must be balanced against the protection of individual rights and civil liberties as integral elements of ICJ.

However, suggesting that the road to reconciliation depends on the protection of democratic values and institutions is problematic. As Drumbl cautions, ${ }^{63}$ states or powerful groups within states may be inherently undemocratic, and transitional justice cannot necessarily be expected to correct power imbalances, such as those in Rwanda, having their roots in tribal cultures that have persisted over centuries. ${ }^{64}$ Nevertheless, it may be possible to strengthen institutional structures and process by developing ties of horizontal and vertical trust among citizens so that there gradually emerges a willingness for all citizens to place trust in achieving common political objectives, protected by a strengthened framework of fundamental rights. ${ }^{65}$

The role of ICJ and international sentencing in particular in addressing these concerns is already important, although limited for the reasons

\footnotetext{
${ }^{62}$ This may not necessarily be significant since some cultures retain retributive justice as having an important role to play in effecting reconciliation and moving towards reconstruction and peace. Retribution will always be a significant component of justice since it not only focuses on the individual offender's need to atone for the harm done, it is the legal authority's symbolic affirmation of a moral disapproval which resides in the wider community. Whether such moral disapproval is representative, either temporally or actually, is a matter for conjecture.

${ }^{63}$ Drumbl $M$ A 'Collective Violence and Individual Punishment: The Criminality of Mass Atrocity’ (2005) 99 Northwestern University Law Review 539, 598.

${ }^{64}$ See, Alvarez J E 'Crimes of States/Crimes of Hate: Lessons from Rwanda' (1999) 24 Yale Journal of International Law 365; Aukerman $M J$ 'Extraordinary Evil, Ordinary Crime: A Framework for Understanding Transitional Justice’ (2002) 15 Harvard Human Rights Journal 39.

65 See, International Centre for Transitional Justice, 'Reconciliation' (2006) on the question of developing a 'Civil Trust Model of Reconciliation'.
} 
previously discussed. However, it has the potential to become much more significant. Developing a sense of civil society through building trust should be envisaged as something which is essentially relational and communitarian; relational in the sense that trust itself emerges through strengthening relationships, and communitarian in that the moral integrity of a society's ideological foundations depends on a sharing of ideals, and a will to carry through their common purpose. For ICJ, its structures and processes, the challenge is not simply one of the relativity of justice in the immediate locality of war and social conflict. It is much greater, in that ICJ seeks to reflect justice for the local and the global.

For this reason, Norrie's ${ }^{66}$ observations concerning the relationality of justice are quite apposite, especially his recognition that processual norms and rights must relate to the legal and moral context of criminal action and punishment. In Norrie's view, a relational model of justice is concerned to examine the connections between responsible individuals and communities so that punishment is envisaged as part of that shared experience. Norms of access and rights conceived in these terms implies a sharing of the justice process; namely, that rights should no longer be conceived as a distinct set of normative constraints on process, but rather as an integral and inseparable component of relational justice. In effect, for international penality such a conceptualisation envisages meaningful connections between the universality of rights and their application in context.

Held $^{67}$ also argues in favour of foundations for a morality of justice consistent with promoting the kind of relational justice advocated by Norrie. She makes an important distinction between the ethics of justice and the ethics of care. ${ }^{68}$ The former focuses on issues of fairness, equality and individual rights; looking for impartial and abstract principles which can be applied consistently across particular cases. The latter focuses on attentiveness to context, trust, responsive to needs, cultivating caring relations. Instead of promoting equality and freedom from interference (autonomy), care values promote positive involvement with others and foster social bonds. Held suggests ${ }^{69}$ that justice should be developed within

\footnotetext{
${ }^{66}$ Norrie A Punishment, Responsibility and Justice (Oxford: Oxford University Press, 2000)

${ }^{67}$ Held $V$ 'Care and Justice in the Global Context' (2004) 17 Ratio Juris 141.

${ }^{68}$ Ibid, 144.

69 Ibid, 147.
} 
contexts of caring relations, cautioning that the domain of law (with justice as its priority) should be seen as a limited domain; not one imagined for the whole of moral life.

Repairing relationships, building trust and working towards reconciliation and peace through ICJ is not a paradox. However, it can only begin once there exists more profound contextual knowledge about the relativity of justice; hoping to reflect the pluralistic values and methods for achieving justice of different cultures and traditions, whether or not these happen to coincide with state boundaries. ${ }^{70}$

An important example is the recent work by Kiza and Rohne, ${ }^{71}$ which makes a significant contribution to understanding the nature of victimization and its consequences for achieving justice in societies traumatised by war and social conflict. The authors' extensive quantitative analysis is developed from a sophisticated conceptualisation of war victimization that enables them to interrogate and evaluate a wide variety of attitudes concerned with the perceptions of victims towards the punishment of those responsible for mass atrocity in the Balkans, Israel and Palestine, and the Darfur region of the Sudan. They address questions about the legal foundations for trial justice, victims' perceptions of the purpose or appropriate means for providing it, and victims' attitudes towards the type and appropriateness of the sanctions currently available. This study begins to establish the kind of knowledge about war victimology that is necessary as international trial justice attempts to find ways to involve war victims more effectively and so enhance the legitimacy of the structures and outcomes of international criminal trials.

Significantly, this insightful type of contextual research also has particular significance for Findlay and Henham's ${ }^{72}$ recent polemic on transforming ICJ. It sends out a clear signal to those responsible for administering international trial justice of the pressing need for greater

\footnotetext{
${ }^{70}$ Such deep and multi-layered empirical knowledge can only result from the kind of penetrating comparative contextual analysis advocated by Findlay and Henham; supra, note 60 .

${ }^{71}$ See Kiza E and Rohne R Victims’ Expectations: The International War-Victim Survey (Freiburg: Max Planck Institute for Foreign and International Criminal Law, 2005). See further; Albrecht $H-J$ et al (eds.) Conflicts and Conflict Resolution in Middle Eastern Societies: Between Tradition and Modernity (Berlin: Duncker and Humbolt, 2006). ${ }^{72}$ Supra, note 60.
} 
inclusivity in order to increase the perceived legitimacy of sentencing outcomes. Ultimately, therefore, international penality must be recognised as fulfilling some kind of moral purpose; that of delivering perceptions of legitimate punishment in situations of mass violence. There will always remain problems of translating this aspiration into practice because justice is essentially a moral and relative issue. Changing the ideological purpose and normative framework of ICJ is a vital precursor to such an endeavour. This need for conceptual change is equally consistent for those who see their global responsibilities as being concerned with developing the ethics of care, ${ }^{73}$ as it is with the notion that international sentencing must be able to connect with other forms of adjudication or intervention strategies which are deemed necessary for promoting transitional forms of justice delivery.

As Simon suggests, ${ }^{74}$ the adoption of a functional approach to resolving the role of criminal accountability is preferable where 'reconciliation ${ }^{, 75}$ is the declared goal for justice in the wake of political mass violence. The fundamental point is that the appropriate balance between retributive and restorative forms of justice should be determined by reaching some accommodation with global and local expectations for achieving justice following collective violence, thereby investing sentencing decisions with legitimacy and authority.

If the necessary ideological commitment and political will exists, then more constructive strategies and interventions could be built into the trial process itself, so that 'punishment' in the conventional sense is only one possible outcome. This proposition partly begs the question whether, for example, as Tallgren implies, ${ }^{76}$ the purpose of ICJ is essentially symbolic, therefore undermining the possibility of rational governance in any global sense, serving merely to mystify the underlying realities of power and political control; effectively an excuse to marginalise those whom wealthy states, individuals or global corporations wish to exclude. ${ }^{77}$

${ }^{73}$ Held, supra, note 67.

${ }^{74}$ Simon $J$ 'Criminal Law dealing with Political Mass Violence in South Africa, Rwanda and El Salvador' (Freiburg: Max Planck Institute for Foreign and International Criminal Law, Research Note, undated) 6.

${ }^{75}$ Ibid, ‘... 'reconciliation' does not have a normative status but rather is a term varying with the needs of different societies.

${ }^{76}$ Supra, note 8, 594.

${ }^{77}$ C,f. Mathiesen's Foucaultian analysis of the social functions of imprisonment. Mathiesen T Prison on Trial (London: Sage Publications, 1990). 
In response, I would argue that the transformation of international trial justice will counter some of these negative conclusions. Although it may not impact on the abuse of power or the conduct of international relations, what it will do is to prevent international trials from being so readily manipulated by the agencies of international social control, ${ }^{78}$ symbolically or otherwise. It will become more difficult to marginalise the weak and stigmatise those who threaten the stability of existing structures of hegemony. Although, as Parmentier suggests, ${ }^{79}$ structures of accountability cannot stand alone, I would not endorse his suggested demarcation of responsibilities between retributive and restorative structures as distinct alternatives for pursuing justice.

Notwithstanding, as Drumbl argues, ${ }^{80}$ whilst asserting the rule of law and legalism does nothing to de-politicize the nature and causes of mass violence; it remains an open question as to the extent to which international trials are more or less open to political contamination than other forms of intervention and resolution.. The building of civil society includes the careful and gradual creation of bonds of trust between citizens and the agents of social control. The kind of ideological reconstruction advocated by Findlay and Henham ${ }^{81}$ stretches the conceptual horizons and capabilities of international trials by making them much more responsive to the demands of social forces, as urged by Fletcher and Weinstein ${ }^{82}$. Thus, the construction rather than symbolic manufacture of justice solutions will make some contribution to peace and reconciliation where none existed previously, or was deemed possible. ${ }^{83}$

\footnotetext{
${ }^{78}$ Namely, powerful states and international organisations

${ }^{79}$ Supra, note 27

${ }^{80}$ Supra, note 7, 24. More recently, Drumbl invokes cosmopolitan theory to sustain the idea of pluralism in ICJ and argues for the acceptance of flexible and alternative paradigms such as tort, contract and restitution, so that the universal norms of accountability are rendered relational. He suggests that, whilst rejecting notions of collective guilt, notions of collective responsibility and collective sanction do not recognise the collective nature of the violence; see, Drumbl $M$ 'Atrocity and Punishment' (Washington \& Lee University Public Law and Legal Theory Research Paper Series, Working Paper No. 05-18, November 2005) 20-22.

81 Supra, note 60.

82 Supra, note 30.

${ }^{83}$ In this Parmentier is surely correct in suggesting the need for research on the relationship between retributive and restorative mechanisms to deal with crimes of mass violence, or helping to develop a 'restorative diplomacy of peace'; See Braithwaite J
} 
The mobilisation of judicial discretion for the purposes of transforming $\mathrm{ICJ}^{84}$ will depend on a cooperative project to reposition the international criminal trial and reflect a more restorative and inclusive influence. As argued, such a project is possible only if those normative structures put in place are developed from a strong ideological foundation to which the relevant State Parties and international judiciary are formally and creatively committed. Along with this is the essential acceptance and cooperation of victim communities which will legitimate any such normative framework, as well as crucially participating in efforts to make these normative frameworks, and the discretion they enable, accountable.

Professional actors in the trial will therefore be instrumental in recognising and protecting the interests of victims and communities; so reducing formalism and promoting inclusivity. The move will necessarily be away from an adversarial towards a collaborative commitment. This does not mean that the legitimate aspirations for retribution will be rejected. Rather, these will be required to co-exist with other important aspirations of victims and communities, which the judge, and the legal professionals, will be called upon to balance and recognise.

In this the discretionary power of international judges and their ability to identify and address the interests of the victim and the community and to ensure that their voices are heard will be pivotal. This will also involve broadening accountability under the overriding direction and supervision of the judge. It will also, as part of the collaborative endeavour, mean that the exercise of professional discretion will be made more accountable to legitimate community interests, even when these may be in conflict.

Specifically, the trial will become a process of decision-making wherein the judge will direct an essentially truth-focussed enterprise towards outcomes which can be retributive, restorative, or degrees of both depending on the appropriate and achievable recognition of the legitimate interests of victim communities. This requires a more collaborative notion of justice which endeavours to connect with the developing place of victims within

Restorative Justice and Responsive Regulation (Oxford: Oxford University Press, 2002) 169-171.

84 As outlined in Findlay and Henham, supra, note 60. 
restorative justice and feature conceptualisations of victim access and interests beyond measures of individual harm and just deserts.

Findlay and Henham's belief that law should be viewed as instrumental and transformative is evidenced by an equation of access to justice with a distinct conceptualisation of victim participation, suggesting that victims should participate fully and have a significant input into discretionary decision-making processes occurring throughout the criminal trial. Judicial discretion will be essential to enable effective collaboration between diverse victim interests, professional commitments, and the wider community aspirations for trial justice.

Effective accountability is crucially important for connecting with notions of restorative justice that resonate with the concerns of victims and communities. Findlay and Henham argue that accountability processes can be established and made workable when the interests of trial participants may seem to conflict. The crucial question is whether the international trial is to remain primarily a process wherein such conflict is determined, or one which mediates conflicting interests to produce outcomes that are relevant to promoting the transition from war to peace. ${ }^{85}$

${ }^{85}$ These ideas and the structures for their implementation are elaborated in Findlay $M$ and Henham $R$ Beyond Punishment: International Criminal Justice Achieved (forthcoming). 